\title{
The Effect of Gum Arabic on Energy Balance Genes in Mouse Liver
}

\author{
Jaafar Suleiman Fedail ${ }^{1}$, Hassan Hussein Musa ${ }^{2^{*}}$ \\ Abdelkareem Abdalla Ahmed ${ }^{3}$, Amal Zakria Sifaldin ${ }^{3}$ and Taha Hussein Musa ${ }^{4}$ \\ ${ }^{1}$ Department of Biology, Faculty of Education, University of Nyala, Nyala, Sudan. \\ ${ }^{2}$ Faculty of Medical Laboratory Sciences, University of Khartoum, Sudan. \\ ${ }^{3}$ Department of Physiology and Biochemistry, Faculty of Veterinary Sciences, University of Nyala, \\ Sudan. \\ ${ }^{4}$ Key Laboratory of Environmental Medicine Engineering, Ministry of Education, Department of \\ Epidemiology and Biostatistics, Southeast University, School of Public Health, 210009 Nanjing,
} Jiangsu Province, China.

\section{Authors' contributions}

This work was carried out in collaboration between all authors. Authors JSF, HHM and AAA designed the study, performed the statistical analysis, wrote the protocol, and wrote the first draft of the manuscript. Authors AZS and THM managed the analyses of the study. Author HHM managed the literature searches. All authors read and approved the final manuscript.

Article Information

DOI: 10.9734/JAMMR/2017/35322

Editor(s):

(1) Rosaria Meccariello, Biology, Universita di Napoli Parthenope, Dipartimento di Scienze Motorie e del Benessere, Italy.

(2) Alex Xiucheng Fan, Department of Biochemistry and Molecular Biology, University of Florida, USA

Reviewers:

(1) Kevin Urstadt, University of Michigan, USA. (2) Anonymous, Università Cattolica Medical School, Italy. (3) Rosa Elena Navarro Hernandez, Guadalajara University, Mexico. (4) Júlio Cezar De Oliveira, Federal University of Mato Grosso, Brazil. Complete Peer review History: http://www.sciencedomain.org/review-history/21385

Original Research Article

Received $7^{\text {th }}$ July 2017 Accepted $19^{\text {th }}$ September 2017 Published 13 ${ }^{\text {th }}$ October 2017

\section{ABSTRACT}

Aims: Energy homeostasis is regulated by a complex neuroendocrine system including appetite regulatory hypothalamus peptides and adipocytes derived peripheral signals. The aim was to study the effects of Gum Arabic on fat mass and obesity-associated gene expression in liver.

Study Design: This case control study was conducted at Key laboratory of Biochemistry, Nanjing Agricultural University, China. 
Methodology: Female C57BL/ $6 \mathrm{~J}$ mice at 13 weeks of age were treated with $10 \%$ of gum Arabic in drinking water for 12 weeks. Food intake, body weight, visceral adipose tissue (VAT), blood glucose and lipids profiles were measured. The expression of energy balance related genes was measured by Real-time PCR.

Results: Gum Arabic significantly $(P<0.05)$ decreased food intake, body weight, and VAT accumulation. Gum Arabic significantly $(P<0.05)$ decreased blood glucose, total cholesterol, and LDL-C, whereas increased high- density lipoprotein (HDL). Gum Arabic had no significant effect on the expression of neuropeptide Y (NPY), adenosine monophosphate (AMP), agouti (Ago) protein and fat mass and obesity-associated protein (FTO) in the liver.

Conclusion: Gum Arabic had significant effect on food intake, body weight and VAT associated with decreased blood glucose and lipid profiles, without any change in the expression rate of energy homoeostasis genes.

Keywords: Gum Arabic; gene expression; energy balance genes; mice.

\section{INTRODUCTION}

Obesity is a state of increased abdominal fat deposition consequential from chronic nutrient intake, where energy intake exceeds energy expenditure [1]. Energy expenditure was influenced by basal metabolism rate [2], physical activity [3], body size and lifespan [4], and thermogenesis [5]. Disturbances of central [6] and peripheral [7] signals may lead to obesity and anorexia. Obesity poses a risk factor for hypertension, diabetes, hyperlipidemia, cancer and other metabolic disorders. In addition, obesity regulates food intake, appetite and fat deposition [8]. Energy homeostasis is regulated by a complex neuroendocrine system including appetite regulatory hypothalamic peptides [9], adipocytes-derived peripheral signals such as leptin [10]. These signals are integrating information about energy status [11]. Among all the cerebral circuits involved in the regulation of feeding behavior and energy balance, the hypothalamus seems to play a significant role in the orchestration of several neurotransmitters essentials to the fine tune of these behaviors [12].

A variety of orexigenic and anorexigenic neuropeptides have played a critical role in food intake and energy balance [13]. For instance, orexigenic neuropeptides include orexin (ORX) [14], agouti protein (Ago) [15] and neuropeptides $Y$ (NPY) [16] after, and anorexigenic neuropeptides such as corticotropin releasing hormone $(\mathrm{CRH})$ [17], proopiomelanocortin (POMC) [18], glucagon-like peptide-1(GLP-1) [19], and AMP activated protein kinase (AMPK) [20] control food intake. However, previous study has indicated that FTO has a significant effect on body mass index (BMI) and increased food intake [21]. In addition, others studies showed that hypothalamic expression of NPY, FTO, POMC, AMP, and Ago have an important role in food intake and energy homeostasis $[9,22]$.

Gum Arabic is edible dried sticky exudates rich in soluble fiber. It is used in food and pharmaceutical industry as an emulsifier and preservative [23]. Studies showed that a high ingestion of dietary fiber, including Gum Arabic, is associated with beneficial effects on fat metabolism [23,24]. Dietary fiber can manage body weight by altering glycaemic index and affecting gastric and gut hormone secretion [25].

Recently, the effect of Gum Arabic on the expression of lipid metabolism genes was studied [26]; effects on the reduction of abdominal fat accumulation and its association with the downregulation of $11 \beta$-hydroxysteroid dehydrogenase expression have been reported in mice liver and muscle [27]. The aim of this study was to determine the effect of Gum Arabic on energy balance related genes expression in the liver of mice.

\section{MATERIALS AND METHODS}

\subsection{Experimental Animals}

This is a case control study conducted in the Key laboratory of Biochemistry, Nanjing Agricultural University, China. Gum Arabic used in this study was from Acacia Senegal tree from Sudan. Twenty female C57BL/ $6 \mathrm{~J}$ mice at 13 weeks of age were housed in plastic cages (each containing five mice) kept in a room at $25^{\circ} \mathrm{C}$ with a $12 \mathrm{hr}$ light and dark cycle. The mice were allowed free access to a commercial pelleted diet for the adaptation and drinking water throughout the experiment. After 3 days of acclimatization, the mice were divided into control and gum 
Table 1. Primers used for real-time PCR

\begin{tabular}{|c|c|c|}
\hline Target genes & PCR products (bp) & Primer sequences \\
\hline GAPDH & 300 & $\begin{array}{l}\text { F : 5'- ACATGGTCTACATGTTCCAGTA -3' } \\
\text { R : 5'- GGAGTCTACTGGTGTCTTCA -3' }\end{array}$ \\
\hline FTO & 200 & $\begin{array}{l}\mathrm{F}: 5^{\prime}-\text { AGCAGAGCAGCCTACAAC-3' } \\
\mathrm{R}: 5^{\prime}-\mathrm{CTGGACTCGTCCTCACTTT}-3^{\prime}\end{array}$ \\
\hline NPY & 168 & $\begin{array}{l}\text { F: 5'- AGGTAACAAGCGAATGGG -3' } \\
\text { R: 5'- AGATTGATGTAGTGTCGCAGA -3' }\end{array}$ \\
\hline AMP & 111 & $\begin{array}{l}\text { F: 5'- GCCGACTTTGGTCTTTCA-3' } \\
\text { R: 5'- GCCTGCGTACAATCTTCC-3' }\end{array}$ \\
\hline Agouti & 186 & $\begin{array}{l}\text { F: 5'- TCCCAGGTCTAAGTCTGAATG -3' } \\
\text { R: 5'- ACGGGTCGCAGCAAGGTA -3' }\end{array}$ \\
\hline
\end{tabular}

Arabic groups each with 10 mice. Gum Arabic mice group received $0.5 \%$ of gum Arabic aqueous solution as drinking water for 7 days, and then $10 \%$ solution for the further 12 next weeks. The control group was given water through the experimental period. Body weight and food intake was measured during the experiment. In addition, fasting blood samples were collected from all mice. Then mice were killed at the end of the experiment, liver and visceral adipose tissues were dissected, weighed and stored at $-80^{\circ} \mathrm{C}$. The experimental procedures were approved by the Animal Ethics Committee of Nanjing Agricultural University (Nanjing, China).

\subsection{Plasma Lipid Profile}

Blood glucose, total cholesterol, triglyceride, HDL-C and LDL-C, were assayed using kits purchased from Nanjing Jiancheng Bioengineering Institute (Nanjing, China).

\subsection{Gene Expression}

About $100 \mathrm{mg}$ of liver was ground in liquid $\mathrm{N}_{2}$, and $50 \mathrm{mg}$ was used for RNA extraction using TRIzol total RNA kit (Invitrogen, Biotechnology Co, Ltd, Carlsbad, CA, USA) according to the manufacturer's instruction. Complementary DNA was synthesized using Prime Script RT reagent kit according to the manufacturer's instruction (Takara). The effect of Gum Arabic on the expression of energy balance related genes in mice was detected using real-time PCR performed in Mx3000P (Stratagene, USA). Specific primers for NPY, FTO, Ago, and AMP (Table 1 above) were synthesized by Geneary (Shanghai, China). Mice GAPDH served as a reference gene for normalization purposes. The method of $2^{-\Delta \Delta \mathrm{Ct}}$ was used to analyze the realtime PCR data $[28,29,30]$.

\subsection{Statistical Analysis}

Data are expressed as the mean \pm SEM and compared by Student's $t$ - test, $P<0.05$ was considered significant. All statistical analyses were performed using SPSS 16.0 software (SPSS, Chicago, IL, USA).

\section{RESULTS}

\subsection{Body Weight and Food Intake}

Gum Arabic significantly decreased body weight and food intake $(P<0.05)$, and visceral adipose tissue accumulation $(P<0.01)$, while has no significant effect on liver weigh $(P<0.05)$ Fig. 1.

\subsection{Plasma Lipid Profile}

Gum Arabic significantly decreased $(P<0.05)$ blood glucose, total cholesterol, and LDL-C. In addition, Gum Arabic significantly increased $(P<0.05)$ the level of HDL-C, and had no significant effect on triglyceride Table 2.

\subsection{The Expression of Energy Balance Related Genes}

The results have shown that Gum Arabic had no significant effect on the expression of the energy balance related genes NPY, AMP, Ago protein and FTO in liver Fig. 2.

\section{DISCUSSION}

The obesity results from fast food consumption with poor dietary outcomes [31]. Obesity plays a significant role in the development of many diseases [32], such as, type 2 diabetes [33] and cancer [34]. Supplementation with Gum Arabic in drinking water significantly decreased body 
weight and food intake. This may be because a high intake of dietary fiber, including Gum Arabic was associated with beneficial effects on fat metabolism [23,24]. In addition, the dietary fiber was promoting satiety and satiation, alter glycaemic index, affects gastric emptying, stomach hormone secretion and reduces weight [25]. Moreover, Gum Arabic inhibits absorption of glucose in the intestine via interaction with membrane abundance of SGLT1 in mice [35].

Abdominal obesity is associated with metabolic syndrome [36], and metabolic syndrome is considered a fatal consequence of visceral obesity [37]. In the current study, Gum Arabic significantly decreased the accumulation of VAT in mice submitted to $10 \%$ of Gum Arabic in drinking water. Similarly, $1 \%$ of Gum Arabic in drinking water was reduced VAT [38]. Gum Arabic, dietary fiber may prevent obesity by several mechanisms for example via lowering caloric density of food [39], and/or decreasing fat absorption in the small intestine [40]. The reduction in the VAT mass may be a consequence of a lower caloric intake. Since a dietary fiber are believed to reduce food intake [39], after study soluble dietary fiber may have the potential effects to limit cholesterol and fat
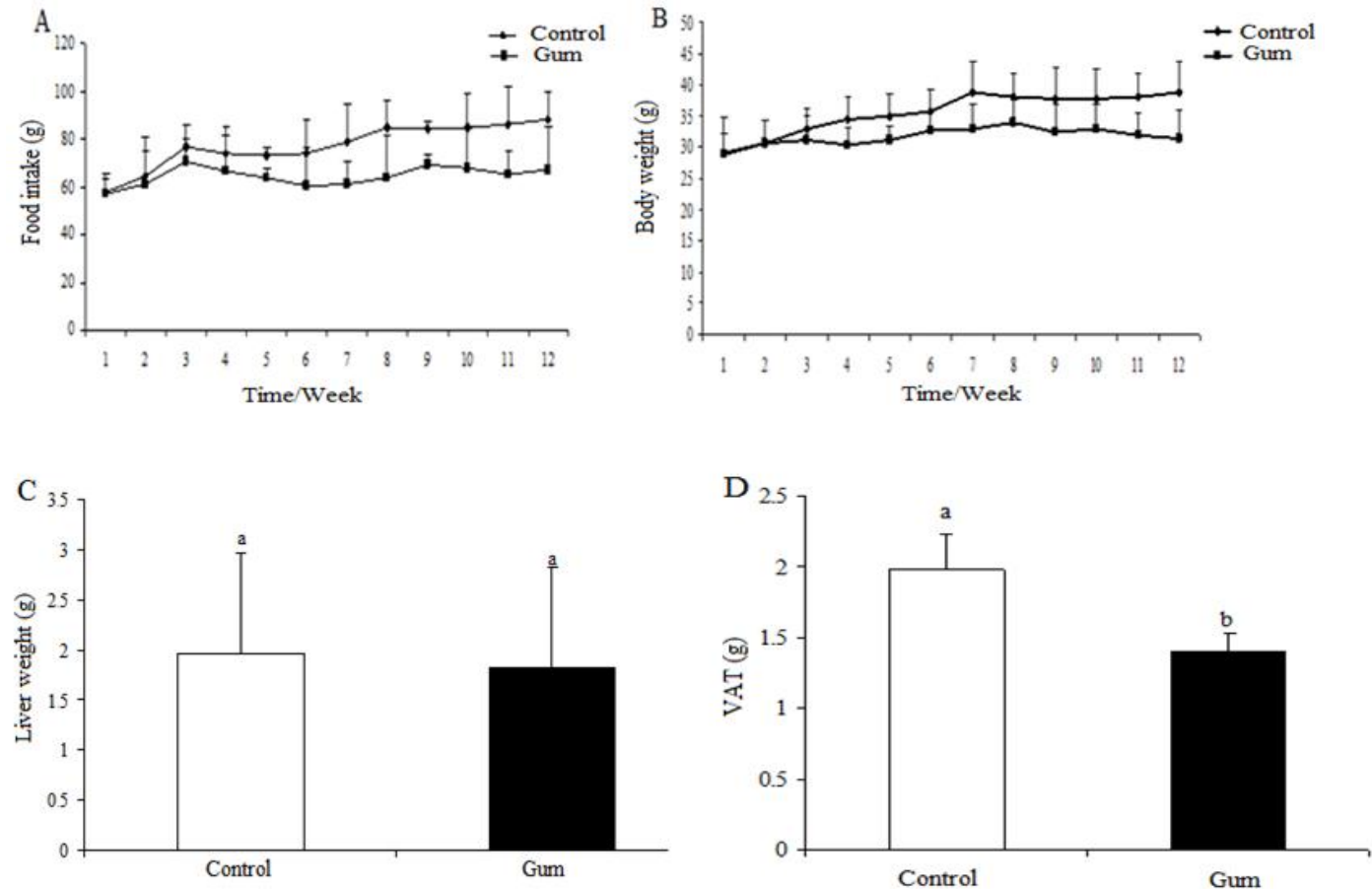

Fig. 1. The effect of gum Arabic on food intake (A), body weight (B), Liver weight (C) and VAT (D)

The values are expressed as means \pm SEM, $n=10$ /group. Different superscript letters above the bars indicate significantly different mean values at $P<0.05$.

Table 2. Effect of gum Arabic on blood glucose and lipid profile

\begin{tabular}{llllll}
\hline Group & $\begin{array}{l}\text { Glucose } \\
(\mathbf{m m o l} / \mathbf{L})\end{array}$ & $\begin{array}{l}\text { Triglyceride } \\
(\mathbf{m g} / \mathbf{d L})\end{array}$ & $\begin{array}{l}\text { Total cholesterol } \\
(\mathbf{m g} / \mathbf{d L})\end{array}$ & $\begin{array}{l}\text { HDL-c } \\
(\mathbf{m g} / \mathbf{d L})\end{array}$ & $\begin{array}{l}\text { LDL-c } \\
(\mathbf{m g} / \mathbf{d L})\end{array}$ \\
\hline Control & $7.01 \pm 0.6^{\mathrm{a}}$ & $37.5 \pm 3.1^{\mathrm{a}}$ & $69.1 \pm 1.5^{\mathrm{a}}$ & $55.4 \pm 1.4^{\mathrm{a}}$ & $36.1 \pm 2.33^{\mathrm{a}}$ \\
Gum Arabic & $3.52 \pm 1.5^{\mathrm{b}}$ & $39.2 \pm 1.3^{\mathrm{a}}$ & $49.4 \pm 1.4^{\mathrm{b}}$ & $68.9 \pm 3.5^{\mathrm{b}}$ & $24.2 \pm 2.5^{\mathrm{b}}$ \\
\hline
\end{tabular}

$H D L-c$, high density lipoprotein; $L D L-c$, low density lipoprotein.

Different superscript letters above value indicate significantly different mean values at $P<0.05$. 

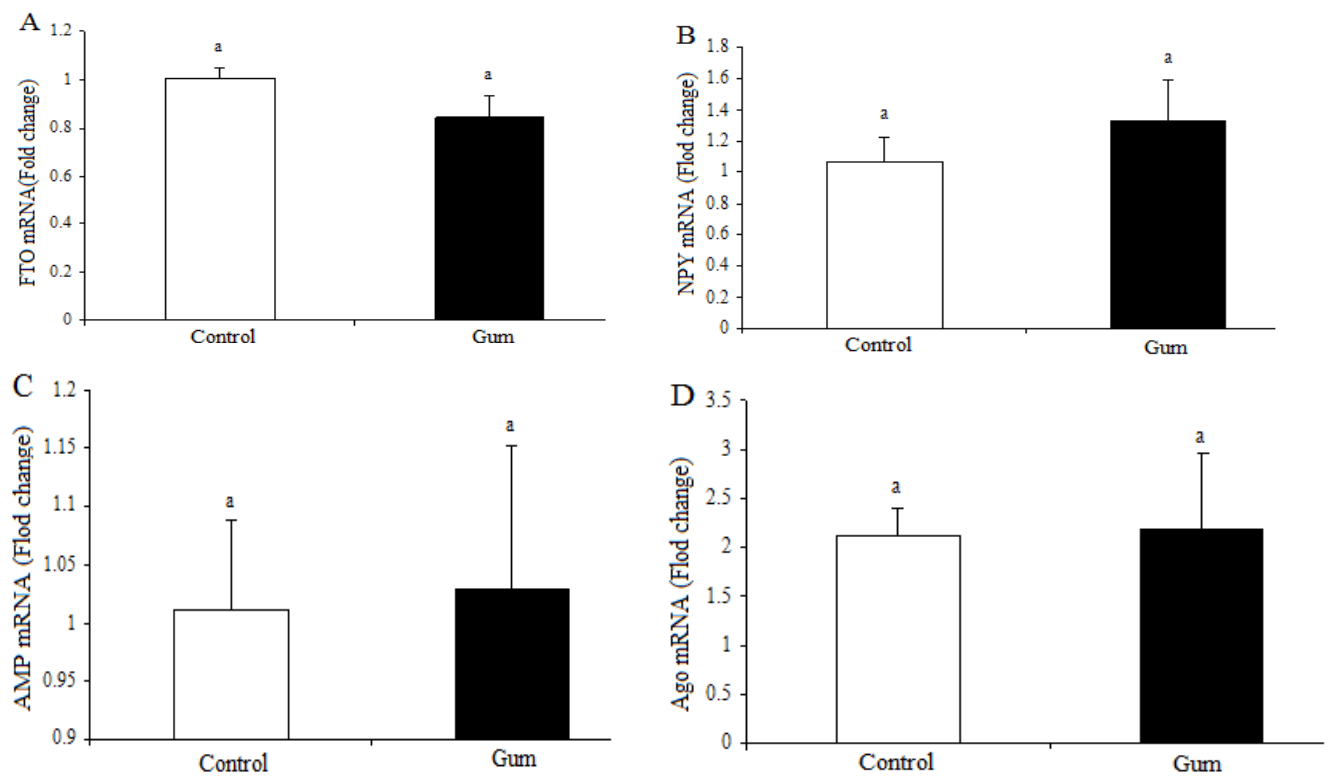

Fig. 2. The effect of Gum Arabic on hypothalamic expression of orexigenic and anorexigenic neuropeptides genes

FTO (A); NPY (B); $A M P(C)$; and Ago (D). The values are expressed as means $\pm S E M, n=6 /$ group. Different superscript letters above the bars indicate significantly different mean values at $P<0.05$.

absorption as proposed previously [41]. Hypothalamic NPY signaling network plays significant roles in the regulation of energy balance [42]. The present study indicated that Gum Arabic doesn't effect the expression of NPY that regulate food intake and energy balance. Further study was needed using male mice to confirm the result since in this study only female mice were used, in which estrus cycle and behavior may effect the results.

\section{CONCLUSION}

The present study indicated that, in the liver, Gum Arabic doesn't affect the expression of energy balance related genes.

\section{CONSENT}

It is not applicable.

\section{ETHICAL APPROVAL}

As per international standard or university standard, written approval of Ethics committee has been collected and preserved by the author(s).

\section{ACKNOWLEDGEMENT}

The authors are highly grateful to Professor Zhao Ruqian and Professor Shi at Nanjing Agricultural University, China for their support to conduct this research.

\section{COMPETING INTERESTS}

Authors have declared that no competing interests exist.

\section{REFERENCES}

1. Morton GJ, Cummings DE, Baskin DG, Barsh GS, Schwartz MW. Central nervous system control of food intake and body weight. Nature. 2006;443(7109):289-295. DOI: $10.1038 /$ nature 05026 .

2. Blundell JE, Caudwell P, Gibbons C, Hopkins M, Erik Naslund, Neil King, et al. Role of resting metabolic rate and energy expenditure in hunger and appetite control: A new formulation. Dis. Mod. Mech. 2012; 5(5):608-613.

DOI: $10.1242 / \mathrm{dmm} .009837$

3. Sallis JF, Erica AH. Reversing the obesity epidemic in young people: Building up the 
physical activity side of energy balance. 2014;2(3):190-191.

Available:http://dx.doi.org/10.1016/S22138587(13)70193-1

4. Speakman JR. Body size, energy metabolism and lifespan. J. Exp. Biol. 2005;208pt9:1717-30.

DOI: $10.1242 /$ jeb.01556

5. Rosen ED, Spiegelman BM. Adipocytes as regulators of energy balance and glucose homeostasis. Nature. 2006; 444(7121):847-853.

DOI: 10.1038/nature05483

6. Avena NM, Bocarsly ME. Dysregulation of brain reward systems in eating disorders: Neurochemical information from animal models of binge eating, bulimia nervosa, and anorexia nervosa. Neuropharmacology. 2012;63(1):87-96.

DOI: 10.1016/j.neuropharm.2011.11.010

7. Izzo AA, Piscitelli F, Capasso R, Aviello G, Romano B, Borrelli F, et al. Peripheral endocannabinoid dysregulation in obesity: Relation to intestinal motility and energy processing induced by food deprivation and re-feeding. Br. J. Pharmacol. 2009; 158:451-461.

DOI: $10.1111 / \mathrm{j} .1476-5381.2009 .00183$

8. Mercer RE, Chee JS, Colmers WF. The role of NPY in hypothalamic mediated food intake. Front. Neuroendocrinol. 2011;32(4): 398-415.

Available:http/doi.org/10.1016/j.yfrne.2011. $\underline{06.001}$

9. $\mathrm{Bi} \mathrm{S}$, Kim YJ, Zheng F. Dorsomedial hypothalamic NPY and energy balance control. Neuropept. 2012;46(6):309-314.

DOI: 10.1016/j.npep.2012.09.002

10. Patterson CM, Villanueva EC, GreenwaldYarnell M, Rajala M, Gonzalez IE, Saini N, et al. Leptin action via LepR-b Tyr1077 contributes to the control of energy balance and female reproduction. Mol Metab. 2012;1(1-2):61-9.

11. Zhang W, Cline MA, Gilbert ER. Hypothalamus-adipose tissue crosstalk: Neuropeptide $\mathrm{Y}$ and the regulation of energy metabolism. Nutr Metab (Lond). 2014;11: 27.

DOI: $10.1186 / 1743-7075-11-27$

12. Funahashi H, Takenoya $\mathrm{F}$, Guan JL, Kageyama H, Yada T, Shioda $S$. Hypothalamic neuronal networks and feeding-related peptides involved in the regulation of feeding. Anat Sci Int. 2003;78(3):123-38.

DOI: 10.1046/j.0022-7722.2003.00055.x

13. Oyama LM, do Nascimento CM, Carnier J, de Piano A, Tock L, Sanches Pde L, Gomes FA, Tufik S, de Mello MT, Dâmaso AR. The role of anorexigenic and orexigenic neuropeptides and peripheral signals on quartiles of weight loss in obese adolescents. Neuropeptides. 2010;44(6): 467-74.

DOI: 10.1016/j.npep.2010.07.002

14. Martin-Fardon R, Boutrel B. Orexin/ hypocretin (Orx/Hcrt) transmission and drug-seeking behavior: Is the paraventricular nucleus of the thalamus (PVT) part of the drug seeking circuitry? Front Behav Neurosci. 2012;6(75):1-6.

DOI: 10.3389/fnbeh.2012.00075

15. Inytska O, Stütz AM, Park-York M, York DA, Ribnicky DM, Zuberi A, Cefalu WT, Argyropoulos G. Molecular mechanisms for activation of the agouti-related protein and stimulation of appetite. Diabetes. 2011;60(1):97-106.

DOI: $10.2337 / \mathrm{db} 10-0172$

16. Pazos P, Lima L, Diéguez C, García MC. Energy balance regulating neuropeptides are expressed through pregnancy and regulated by interleukin- 6 deficiency in mouse placenta. Int. J. Endocrinol. 2014;2014(2014):537-603.

DOI: $10.1155 / 2014 / 537603$

17. Richard D, Huang Q, Timofeeva E. The corticotropin-releasing hormone system in the regulation of energy balance in obesity. Int. J. Obes. Relat. Metab. Disord. 2000; 24 (Suppl 2):S36-39.

18. Wardlaw SL. Hypothalamic proopiomelanocortin processing and the regulation of energy balance. Eur. J. Pharmacol. 2010;660(1):213-19.

DOI: 10.1016/j.ejphar.10.107

19. Hayes MR, De Jonghe BC, Kanoski SE. Role of the glucagon-like-peptide-1 receptor in the control of energy balance. Physiol. Behav. 2010;100(5):503-10.

DOI: 10.1016/j.physbeh.2010.02.029

20. Pimentel GD, Ropelle ER, Rocha GZ, Carvalheira JB. The role of neuronal AMPK as a mediator of nutritional regulation of food intake and energy homeostasis. Metab. 2013;62(2):171-178.

DOI: 10.1016/j.metabol.2012;07.001 
21. Wardle J, Carnell S, Haworth MA, Farooqi IS, Rahilly SO, Plomin R. Obesity associated genetic variation in FTO is associated with diminished satiety. J. Clin. Endocrinol. Metab. 2008;93(9):3640-3643.

22. Martínez de Morentin PB, Whittle AJ, Fernø J, Nogueiras $R$, Diéguez $C$, Vidal-Puig $A$, López $M$. Nicotine induces negative energy balance through hypothalamic AMP-activated protein kinase. Diabetes. 2012;61(4):807-17.

DOI: $10.2337 / \mathrm{db} 11-1079$

23. Ali $\mathrm{BH}$, Ziada A, Blunden G. Biological effects of gum arabic: A review of some recent research. Food Chem Toxicol. 2009;47(1):1-8.

DOI: 10.1016/j.fct.2008.07.001

24. Slavin J. Why whole grains are protective: Biological mechanisms. Proc Nutr Soc. 2003;62(1):129-134.

DOI: 10.1079/PNS2002221

25. Chandalia M, Garg A, Lutjohann D, von Bergmann K, Grundy SM, Brinkley LJ. Beneficial effects of high dietary fiber intake in patients with type 2 diabetes mellitus. N. Engl. J. Med. 2000;342(19): 1392-8.

DOI: 10.1056/NEJM200005113421903

26. Musa HH, Ahmed AA, Musa TH, Fedail JS. Gum Arabic down-regulate PPAR-g and SCD mRNA expression in mice. Pol. Ann. Med. 2015;22(1):11-17.

Available:http://dx.doi.org/10.1016/j.poame d.2015.03.008

27. Ahmed AA, Musa HH, Fedail JS, Sifaldin AZ, Musa TH. Gum arabic decreased visceral adipose tissue associated with downregulation of $11 \beta$-hydroxysteroid dehydrogenase type I in liver and muscle of mice. Bioact. Carbohydr. Diet Fibr. 2015;6(1):31-36.

Available:https://doi.org/10.1016/j.bcdf.201 $\underline{5.06 .004}$

28. Livak KJ, Schmittgen TD. Analysis of relative gene expression using real-time quantitative PCR and the 2(-Delta Delta C(T)) Method. Methods. 2001;25(4):402408.

DOI: 10.1006/meth.2001.1262

29. Ahmed AA, Musa HH, Fedail JS, Sifaldin AZ, Musa TH. Gum arabic decreased visceral adipose tissue associated with downregulation of $11 \beta$-hydroxysteroid dehydrogenase type I in liver and muscle of mice. Bioactive Carbohydrates and Dietary Fibre. 2015;6(1):31-6.

Available:https://doi.org/10.1016/j.bcdf.201 $\underline{5.06 .004}$

30. Ahmed AA, Fedail JS, Musa HH, Kamboh AA, Sifaldin AZ, Musa TH. Gum Arabic extracts protect against hepatic oxidative stress in alloxan induced diabetes in rats. Pathophysiology. 2015;22(4):189-94.

Available:http://dx.doi.org/10.1016/i.pathop hys.2015.08.002

31. Poti JM, Duffey KJ, Popkin BM. The association of fast food consumption with poor dietary outcomes and obesity among children: Is it the fast food or the remainder of the diet. Am. J. Clin. Nutr. 2014;99:162171.

DOI: 10.3945/ajcn.113.071928

32. Lee SY, Chang HJ, Sung J, Kim KJ, Shin $\mathrm{S}$, Cho IJ, et al. The impact of obesity on subclinical coronary atherosclerosis according to the risk of cardiovascular disease. Obesity (Silver Spring). 2014;22(7):1762-1768.

DOI: $10.1002 /$ oby.20760

33. Surani SR. Diabetes, sleep apnea, obesity and cardiovascular disease: Why not address them together. World J. Diab. 2014;5(3):381-384.

DOI: 10.4239/wjd.v5.i3.381

34. De Pergola G, Silvestris F. Obesity as a major risk factor for cancer. J Obes. 2013;291546.

DOI: $10.1155 / 2013 / 291546$

35. Nasir O, Artunc F, Wang K, Rexhepaj R, Föller M, Ebrahim A, Kempe DS, et al. Downregulation of mouse intestinal $\mathrm{Na}(+)$ coupled glucose transporter SGLT1 by gum arabic (Acacia Senegal). Cell Physiol. Biochem. 2010;25(2-3):203-210.

DOI: $10.1159 / 000276554$

36. He F, Rodriguez-Colon S, FernandezMendoza J, Vgontzas AN, Bixler EO, Berg A, Imamura Kawasawa $Y$, et al. Abdominal obesity and metabolic syndrome burden in adolescents-penn state children cohort study. J Clin Densitom. 2015;18(1):30-6. DOI: 10.1016/j.jocd.2014.07.009

37. Di Chiara T, Argano C, Corrao S, Scaglione R, Licata G. Hypoadiponectinemia: A link between visceral obesity and metabolic syndrome. J Nutr Metab. 2012; 175245.

DOI: $10.1155 / 2012 / 175245$ 
38. Ushida $\mathrm{K}$, Hatanaka $\mathrm{H}$, Inoue $\mathrm{R}$, Tsukahara T, Phillips GO. Effect of long term ingestion of gum arabic on the adipose tissues of female mice. Food Hydrocol. 2011;25(5):1344-1349.

Available:https://doi.org/10.1016/j.foodhyd. 2010.12.010

39. Schneeman BO. Dietary fiber: Comments on interpreting recent research. J Am Diet Assoc. 1987;87(9):1163.

40. Vahouny GV, Satchithanandam S, Chen I, Tepper SA, Kritchevsky D, Lightfoot FG, et al. Dietary fiber and intestinal adaptation: Effects on lipid absorption and lymphatic transport in the rat. Am J Clin Nutr. 1988;47(2):201-206.
41. Brownlee IA, Allen A, Pearson JP, Dettmar PW, Havler ME, Atherton MR, Onsøyen E. Alginate as a source of dietary fiber. Crit. Rev. Food Sci. Nutr. 2005;45(6):497-510.

DOI: $10.1080 / 10408390500285673$

42. Semjonous NM, Smith KL, Parkinson JR, Gunner DJ, Liu YL, Murphy KG, et al. Coordinated changes in energy intake and expenditure following hypothalamic administration of neuropeptides involved in energy balance. Int. J. Obes. 2009;33(7): 775-785.

DOI: $10.1038 /$ ijo.2009.96

(c) 2017 Fedail et al.; This is an Open Access article distributed under the terms of the Creative Commons Attribution License (http://creativecommons.org/licenses/by/4.0), which permits unrestricted use, distribution, and reproduction in any medium, provided the original work is properly cited.

Peer-review history:

The peer review history for this paper can be accessed here: http://sciencedomain.org/review-history/21385 